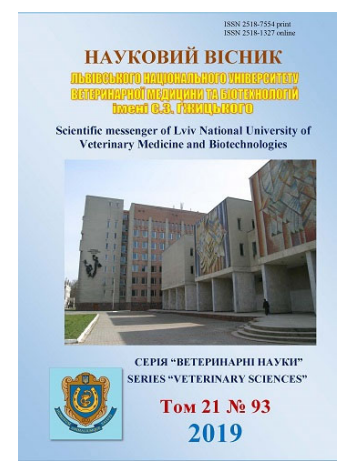

\author{
Науковий вісник Яьвівського національного університету \\ ветеринарної медицини та біотехнологій імені С.3. Гжицького. \\ Серія: Ветеринарні науки \\ Scientific Messenger of Lviv National University \\ of Veterinary Medicine and Biotechnologies. \\ Series: Veterinary sciences
}

ISSN 2518-7554 print ISSN 2518-1327 online doi: $10.32718 /$ nvlvet9301

http://nvlvet.com.ua

UDC 619:616.381-002:636.8

\title{
Pathomorphology of the cerebral cortex of cats for infectious peritonitis
}

\author{
G.I. Kotsyumbas, M.R. Khalaniia
}

Stepan Gzhytskyi National University of Veterinary Medicine and Biotechnologies Lviv, Ukraine

Article info

Received 14.01.2019

Received in revised form 20.02.2019

Accepted 21.02.2019

Stepan Gzhytskyi National University of Veterinary Medicine and Biotechnologies Lviv,

Pekarska Str., 50, Lviv, 79010, Ukraine.

Tel.: +38-032-260-28-89

E-mail: galyna.kotsyumbas@gmail.com
Kotsyumbas, G.I., \& Khalaniia, M.R. (2019). Pathomorphology of the cerebral cortex of cats for infectious peritonitis. Scientific Messenger of Lviv National University of Veterinary Medicine and Biotechnologies. Series: Veterinary sciences, 21(93), 3-9. doi: 10.32718/nvlvet9301

The article presents the results of histological studies of the frontal area of the cerebral cortex6 taken from 10 corpses of cats aged from 3 months to 5.5 years, in which infectious peritonitis (based on anamnesis, clinical signs, morphological and biochemical blood analysis, ultrasound diagnostics, Rivalt test and express diagnosis) was diagnosed during their life. A pathoanatomical study was conducted; samples of the frontal area of the cerebral cortex of cats, which were fixed in a $12 \%$ aqueous solution of neutral formalin, a solution of Carnoua and $96^{\circ}$ ethyl alcohol, were selected. The histocuts were made, which were stained with hematoxylin and eosin, thionine for Nisslem. In order to detect the astrocytic glory, a fraction of the cerebral cortex was fixed by the Golgi-Clatzo method with a fresh mixture of chloral hydrate-formalinbichromate and produced histocuts on a freezing microtome. For histological examination of the cerebral cortex of cats, changes in the non-inflammatory character were observed, which were characterized by disorders of hemomycrocycle circulation, edema and degenerative processes of the neuroglial complex and neurons. Violations of the structural organization of endothelial cells, basal membranes of capillaries and venules should be considered as an important indicator of functional changes in tone, permeability of the microcirculatory channel, which contributed to the development of perivascular and pericellular edema, which in its turn led to regressive changes of glial elements; acute swelling of neurons with the formation of microcavities in nuclei; a sharp decrease in the content of the chromatophilic substance in pyramidal and stellate cells; the development of gidropic dystrophy in star cells and creatures; rise of shadow cells. Circulatory disorders caused the violation of the trophic transport systems, which caused hypoxia, accumulation of acidic metabolism products, and formed the basis for the pathogenesis of the development of dyscirculatory dystrophy of neuroglial cells and neurons, i.e. neurotrophic disorders of the cerebral cortex of cats for FIR.

Key words: cats, infectious peritonitis, FIP, cerebral cortex, astrocytes, neurons.

\section{Патоморфологія кори головного мозку котів за інфекційного перитоніту}

\author{
Г.І. Коцюмбас, М.Р. Халанія
}

Львівський національний університет ветеринарної медицини та біотехнологій імені С.3. Гжищького, м. Львів, Україна

У статті наведені результати гістологічних досліджень лобної ділянки кори головного мозку, які були відібрані від 10 трупів котів, віком від 3 місяців до 5,5 років, у яких прижиттєво було діагностовано інфекційний перитоніт (на основі анамнезу, клінічних ознак, морфологічного та біохімічного аналізу крові, ультразвукової діагностики, тесту Рівальта та експрес-діагностики). Проведено патологоанатомічне дослідження, відібрано взіриі лобної ділянки кори головного мозку котів, які фіксували в 12\% водному розчині нейтрального формаліну, розчині Карнуа та $96^{\circ}$ етиловому спирті. Виготовляли гістозрізи, які фарбували гематоксиліном та еозином, тіоніном за Нісслем. Для виявлення астроцитарної глї шматочки кори головного мозку фіксували за методом Гольджі-Клатцо свіжою сумішшю хлоралгідрату-формаліну-біхромату $і$ виготовляли гістозрізи на заморожуючому мікротомі. За гістологічного дослідження кори головного мозку котів встановлено зміни незапального характеру, які характеризувались розладами гемомікроциркулящії, набряком та дистрофічними процесами нейрогліального комплексу $і$ нейронів. Порушення 
структурної організації ендотеліальних клітин, базальних мембран капілярів та венул варто розглядати як важливий показник функиіональних зміни тонусу, проникності мікроциркуляторного русла, щчо сприяло розвитку периваскулярних $і$ перицелюлярних набряків, а ие своєю чергою вело до регресивних змін гліальних елементів, гострого набухання нейронів з утворенням мікровакуолей в ядрах, різкого зниженню вмісту хроматофільної субстаниії в пірамідних $і$ зірчастих клітинах, розвитку гідропічної дистрофії в зірчастих клітинах та утворення клітин-тіней. Розлади кровообігу зумовили порушення роботи транспортних систем трофіки, що викликало гіпоксію, нагромадження кислих продуктів обміну і лягло в основу патогенезу розвитку дисииркуляторних дистрофій нейрогліальних елементів та нейронів, тобто нейротрофічних порушень кори головного мозку котів за FIP.

Ключові слова: коти, інфекційний перитоніт, FIP, кора головного мозку, астроцити, нейрони.

\section{Вступ}

FIP (інфекційний перитоніт котів) - контагіозне, вірусне захворювання домашніх та диких котів 3 високою летальністю. Найчастіше на FIP хворіють молоді тварини у віці до 3 років і клінічно він проявляється у вигляді вологої або сухої клініко-анатомічної форми. Після появи клінічних симптомів перебіг хвороби може тривати декілька тижнів або місяців. При сухій клініко-анатомічній формі разом із ураженням внутрішніх органів спостерігають зміни в центральній нервовій системі котів (Pedersen et al., 2009; Baydar et al., 2014; Pedersen et al., 2014; Pedersen, 2014a, b; Pedersen et al., 2016; Kim et al., 2016; Ziółkowska et al., 2017). Неврологічні зміни у хворих котів неоднотипні та характеризуються: ністагмом, вестибулярними розладами, судомними нападами, мозочковою атаксією, сповільненням поступальних реакцій на всі кінцівки, неповним зіничним світловим рефлексом, сліпотою з розширенням зіниць та відсутністю відповіді на загрозу (Barnes et al., 2004; Diaz \& Poma, 2009; Pedersen et al., 2009; Rissi, 2009; Ives et al., 2013; Pedersen, 2014 b; Pedersen et al., 2016; Mesquita et al., 2016).

У зарубіжних літературних джерелах повідомлення про гістоструктурні зміни у головному мозку котів за інфекційного перитоніту котів дещо неоднозначні й суперечливі. Американські вчені за мікроскопічного дослідження мозку котів фіксували дифузну інфільтрацію менінгіальної оболонки лімфоцитами і плазматичними клітинами, тобто розвиток лептоменінгіту, а також негнійного енцефаліту (Rissi, 2009). Інші вчені відзначали переважно локальні запальні процеси у перивентрикулярній ділянці, епендимі бічних шлуночків і вентральній частині ромбовидного тіла. Foley та співавтори відзначали розвиток гідроцефалії.

Вивчення структурно-функціональних змін в різних органах і системах та зокрема у головному мозку за різних клініко-анатомічних форм FIP дасть можливість поглибити наші знання щодо варіабельності нейроморфологічних змін і дозволить розкрити окремі питання механізму розвитку хвороби.

\section{Матеріал і методи досліджень}

Патоморфологічні дослідження проводили на кафедрі нормальної та патологічної морфології і судової ветеринарії ЛНУВМБ імені С.3. Гжицького та кафедрі патології Вроцлавського природничого університету (Республіка Польща) протягом 2016-2018 років. Проведено патологоанатомічне дослідження 25 трупів котів, віком від 3 міс. до 7 років, у яких прижиттєво діагностовано FIP (на основі анамнезу, клінічних ознак, морфологічного та біохімічного аналізу крові, ультразвукової діагностики, тесту Рівальта та експрес-діагностики).

Для гістологічного дослідження відбирали фрагменти лобної кори головного мозку розміром $1 \times 1 \mathrm{~cm}$, після чого їх занурили у $96^{\circ}$ етиловий спирт та $12 \%$ водний розчин нейтрального формаліну від 10 трупів котів. Для фіксації, попередньо нашарувавши шар марлі для повного занурення. Потім проводили заливку вирізаних фрагментів тканини в парафін та виготовляли гістозрізи.

Гістозрізи депарафінізували у двох порціях ксилолу по 2 хв в кожній, переносили у спирти знижуючої міцності по 2 хв в кожному $\left(96^{\circ}, 80^{\circ}, 70^{\circ}\right)$ і поміщали у дистильовану воду на 3 хв. Фарбували гістозрізи: гематоксиліном та еозином і за методом Ніссля в розчин тіоніну. Барвник нагрівали до появи випарів, після охолодження зрізи ополіскували у дистильованій воді та $70^{\circ}$ етиловому спирті. Диференціювали в $96^{\circ}$ етиловому спирті, проводили через абсолютний спирт, ксилол і заводили в нейтральний канадський бальзам. Для виявлення астроцитарної глії шматочки кори головного мозку фіксували за методом ГольджіКлатцо свіжою сумішшю хлоралгідрату-формалінубіхромату і виготовляли гістозрізи на заморожуючому мікротомі (Pyrs, 1962; Merkulov, 1969; Goral's'kyj et al., 2005).

Готові гістопрепарати розглядали під світловим мікроскопом Leica DM-2500 (Switzerland), фотографували їх фотокамерою Leica DFC450C 3 програмним забезпеченням Leica Application Suite Version 4.4.

\section{Результати досліджень}

У 10 хворих на FIP котів шерсть набувала матового відтінку, а слизові оболонки були бліді $з$ жовтуватим відтінком. 3 розвитком клінічних ознак поступово змінювались поведінкові реакції, відзначали тремор скелетних м'язів, часткове порушення координації рухів. За макроскопічного дослідження головного мозку відзначали блідість оболонок і тканини мозку, на сагітальному розрізі тканина волога, у 3 котів бокові шлуночки незначно розширені, заповнені прозорою водянистою рідиною (рис. 1, рис. 2).

За гістологічного дослідження лобної ділянки кори головного мозку хворих на FIP котів відзначали значне порушення структури капілярів, венул і артеріол. У розширених просвітах судин мікроциркуляторного русла відсутні формені елементи крові. У більшості ендотеліальних клітинах капілярів та венул розвивались дистрофічні процеси: цитоплазма гомогенна, 
ядра пікнотичні, частіше лізовані (рис. 3). Виявлені зміни у системі гемомікроциркуляції вказували на розлади кровообігу, дезорганізацію транспортних механізмів, що зумовило гіпоксію органу.

Різке розширення просвіту судин супроводжувалось порушенням структури базальної мембрани капілярів, венул. Базальний шар набухлий, розпушений,

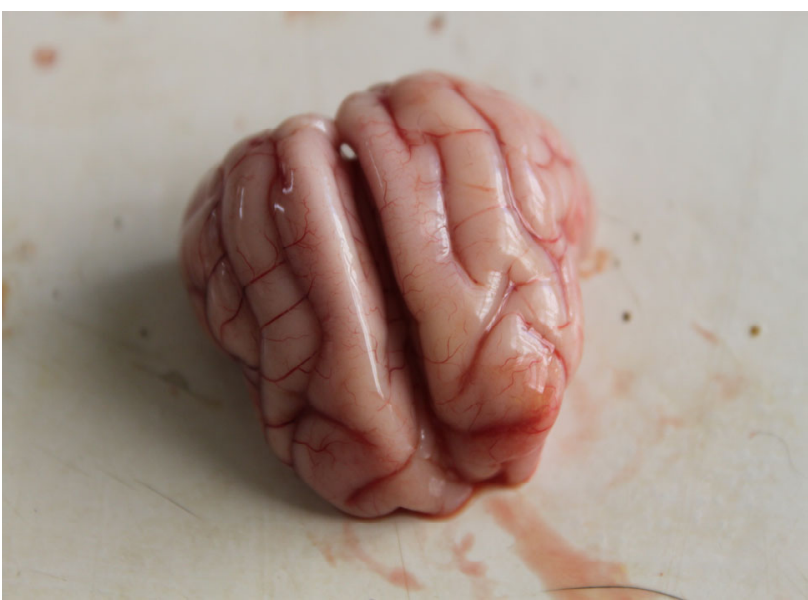

Рис. 1. Головний мозок кота за сухої форми FIP. Анемічність оболонок і тканин головного мозку

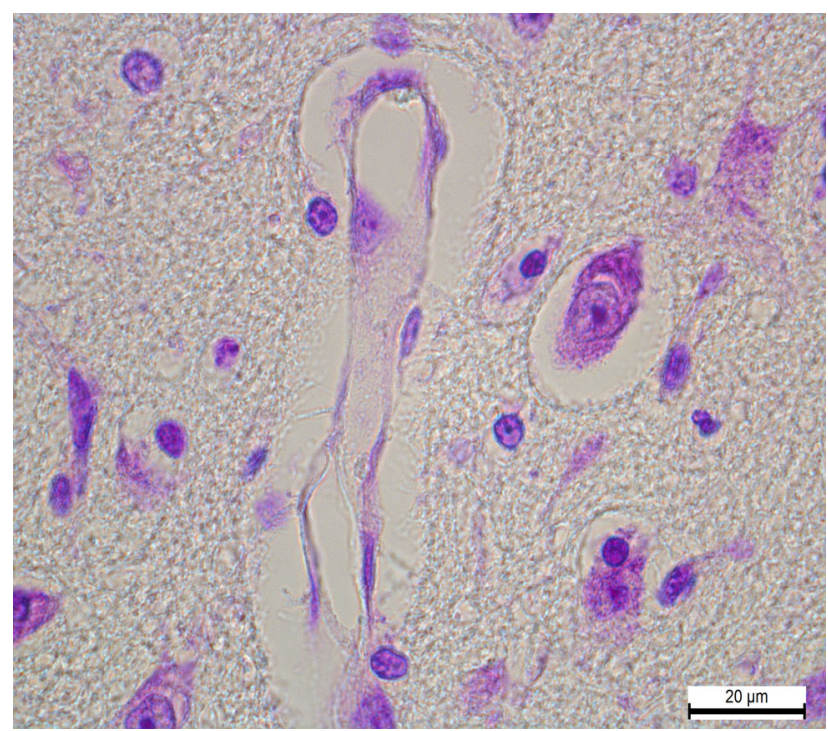

Рис. 3. Кора головного мозку кота. Дистрофія та некробіоз ендотеліальних клітин венули.

Периваскулярний і перицелюлярний набряк. Ніссль. Ок. 10, об. 100

Гістологічно виявлена патологія стінок капілярів та венул кори головного мозку поєднувалась також із розвитком ангіопатій. Просвіт артеріол часто деформований, з інвагінацією стінок і звуженим просвітом. Базальна мембрана гомогенна, набувала світлішого забарвлення, а ядра ендотеліальних клітин часто перебували в стані пікнозу або лізису. У деяких стінках артеріол чітко виділялись поодинокі, дещо збільшені блідо забарвлений, в деяких місцях розплавлений. Навколо капілярні просвіти розширені, просвітлені, 3 ледь помітними павутиноподібними нитковидними структурами, що вказувало на розвиток периваскулярних набряків та набряк відростків гліальних елементів (рис. 4).

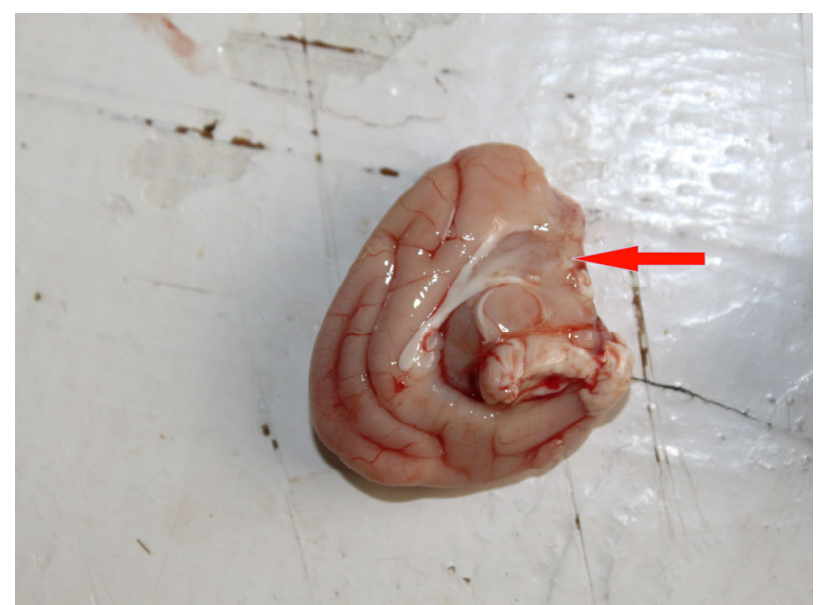

Рис. 2. Сагітальний розріз головного мозку кота. На розрізі тканина волога, боковий шлуночок незначно розширений

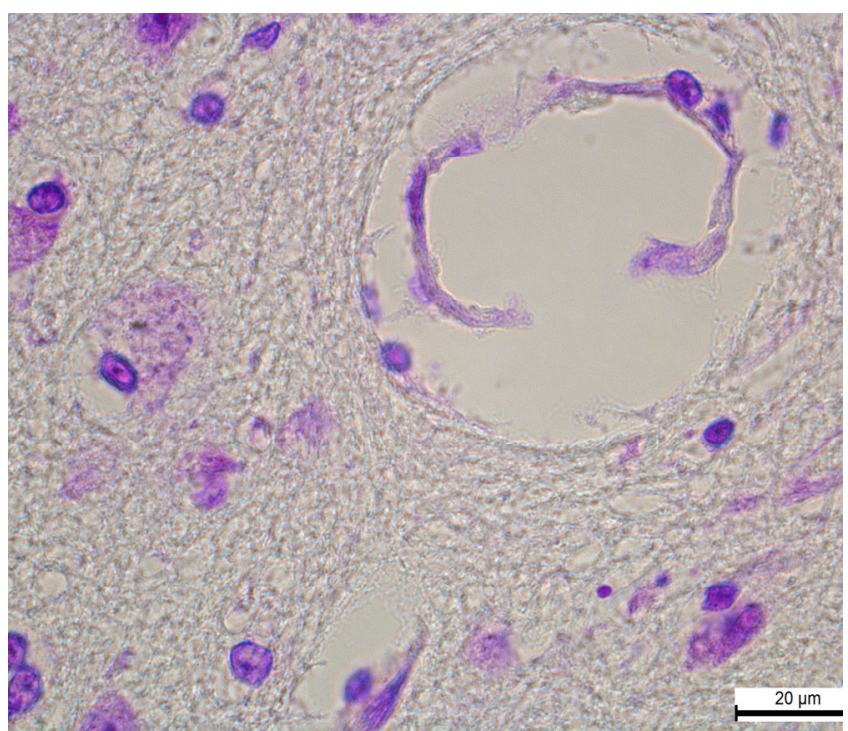

Рис. 4. Кора головного мозку кота. Порушення цілісності стінки венули. Периваскулярний набряк. Ніссль. Ок. 10 , об. 100

ендотеліальні клітини з великими світлими ядрами із зернами хроматину. Витягнутої форми адвентиціальні перицити проглядались на зовнішньому краї артеріоли, але місцями були також лізовані (рис. 5).

У трьох котів у перивентрикулярній ділянці відзначали різку дилатацію судин, що надавало губкоподібного вигляду тканині (рис. 6 ). 


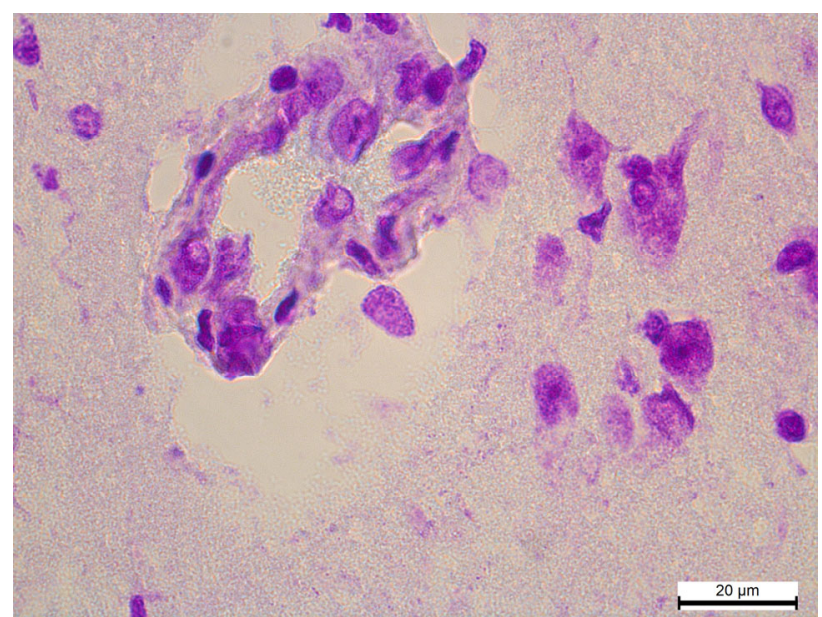

Рис. 5. Кора головного мозку кота. Ангіопатія. Порушення внутрішньої та зовнішньої оболонок артеріоли. Ніссль. Ок. 10, об. 100

У II та III шарах кори головного мозку, внаслідок нагромадження тканинної рідини навколо судин мікроциркуляторного русла, найбільше страждали протоплазматичні астроцити та їхні відростки. На препаратах, забарвлених за Нісслем, виявлені навколо клітинні просвітлені осередки (перицелюлярні набряки) вказували на часткове порушення міжклітинних контактів та зниження метаболічних процесів в клітинах. Тіла макрогліоцитів набухлі, світло-сірі, а ядра 3 вираженим каріорексисом. Варто зазначити, що біля мікросудин переважали астроцити і нейрони з набубнявілими та лізованими ядрами, що вказувало на прогресування некробітичних змін (рис. 7). На препаратах, виготовлених за методом Гольджі-Клатцо добре визначалась дезінтеграція, деструкція, 3 відривом

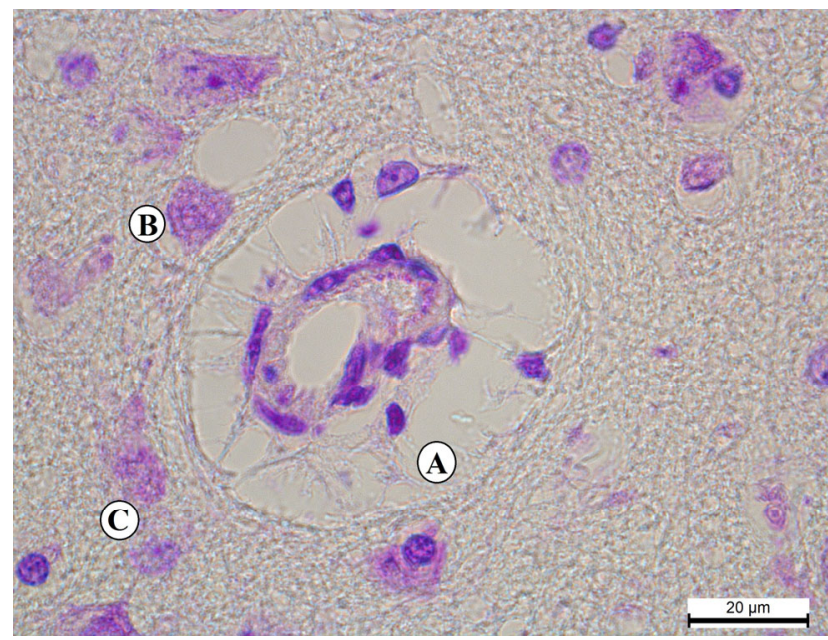

Рис. 7. Кора головного мозку кота:

A - периваскулярний і В- перицелюлярний набряк, C - некробіоз макрогліоцитів. Ніссль. Ок. 10, об. 100

На препаратах, забарвлених гематоксиліном та еозином, ядра зірчастих нервових клітин II і III шарів кори головного мозку набухлі, з множинними мікровакуолями та дрібнозернистою базофільною інкрустацією біля каріолеми і переважно відтиснуті на пе-

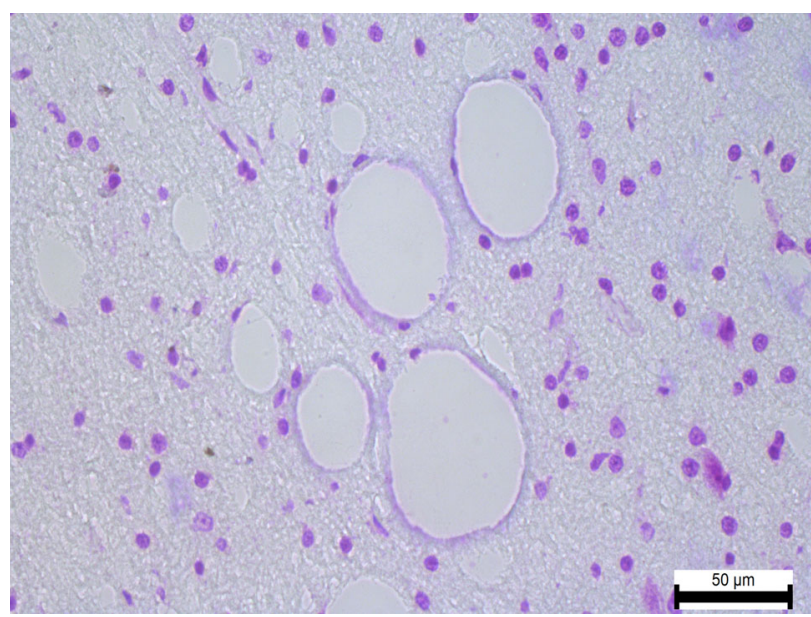

Рис. 6. Перивентрикулярна ділянка мозку кота. Різка дилатація капілярів, венул. Ніссль. Ок. 10, об. 100

окремих або і всіх відростків від тіла протоплазматичних астроцитів (рис. 8). Частіше виявлялись астроцити з втраченими відростками біля судин. Регресивні форми гліальних елементів були також навколо дистрофічно змінених нейронів.

Відомо, що у корі головного мозку більша частина поверхні капілярів оточена відростками гліальних клітин, через міжклітинні щілини мембрани яких відбувається тісний контакт, що $\epsilon$ важливою складовою бар'єрної функції головного мозку. Саме перикапілярна астроцитарна глія забезпечує потреби нейронів у необхідних речовинах, організовуючи вибіркову резорбцію ї із кровоносних судин і транспорт до нейронів (Filimonov, 1959; Ermohin, 1969; Skrebkova, 2004).

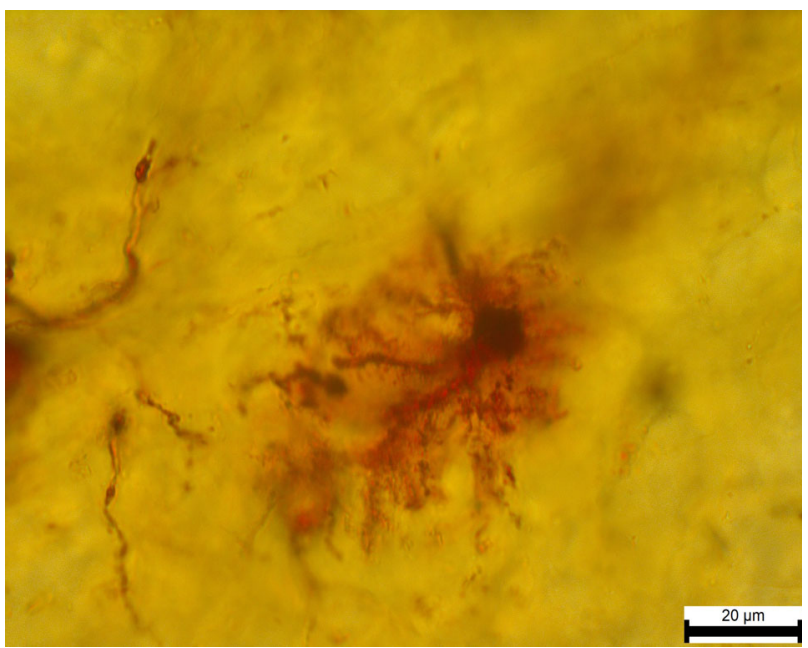

Рис. 8. Дезінтеграція і деструкція окремих відростків протоплазматичних астроцитів.

Гольджі-Клатцо. Ок. 10, об. 100

риферію (рис. 9). Водночас на забарвлених тіоніном препаратах зірчасті нейрони набували переважно неправильної, округлої форми, а в цитоплазмі різко зменшувався вміст хроматофільних грудок. Клітини набухлі, збільшені, з периферичним сегментарним, а в 
деяких - $з$ тотальним хроматолізом. Внаслідок розвитку хроматолізу відбувалася гомогенізація цитоплазми і клітини набували світлішого забарвлення, що свідчило про зниження обмінних процесів в клітинах (рис. 10). Тут варто нагадати, що за інтенсивністю забарвлення нейронів тіоніном за Нісслем оцінюється стан хроматофільної субстанції цитоплазми та функціональна активність клітини. Інтенсивний блакитний

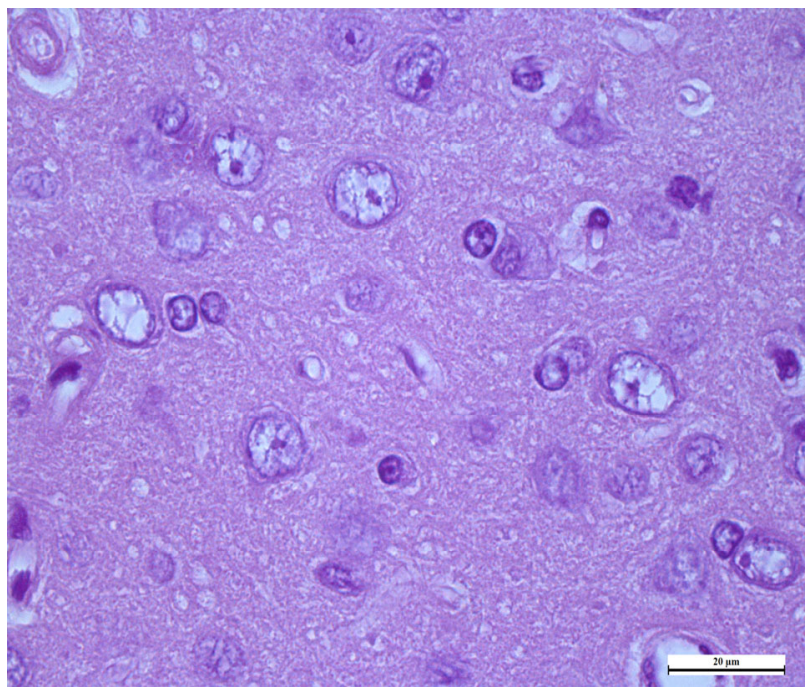

Рис. 9. Гостре набухання зірчастих нервових клітин. Набухлі з множинними мікровакуолями ядра. Гематоксилін та еозин. Ок. 10, об. 100

Частина цитоплазми нейронів, в якій відбувся хроматоліз, погано вбирала тіонін. Спостерігали перерозподіл ядерного хроматину і дрібнозернисте розсіяння його по всій каріоплазмі. Різко знижений вміст хроматину в ядрі супроводжувався збільшенням розмірів ядерець. Ядра 3 круглими ядерцями частіше розміщувались у центрі клітини. В зірчастих нервових

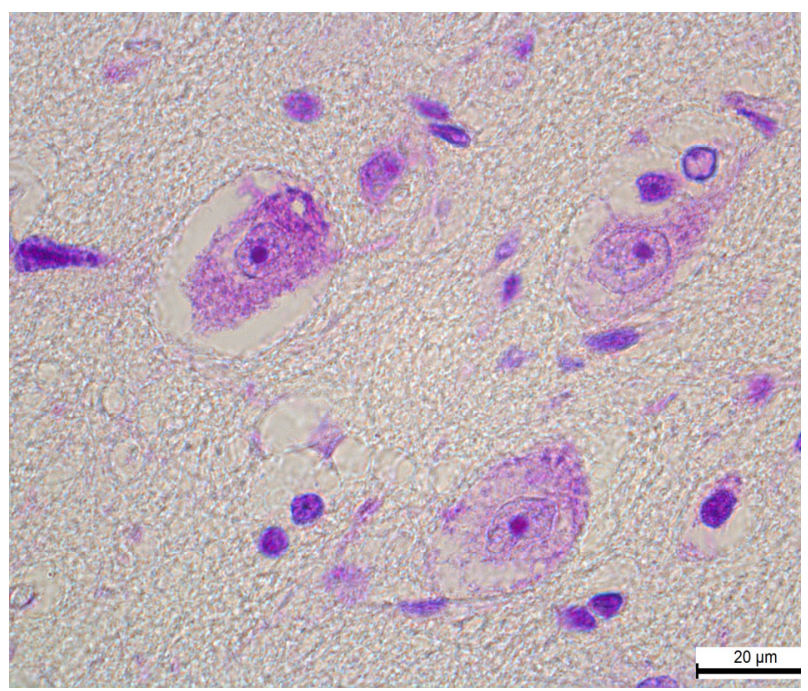

Рис. 11. Кора головного мозку кота. Перицелюлярний набряк. Зниження вмісту хроматофільної речовини у цитоплазмі нейронів. Ніссль. Ок. 10, об. 100 колір нейроплазми свідчить про високий вміст хроматофільної речовини та $є$ показником активного білкового обміну, окисно-відновних процесів та роботи ферментативних систем клітини. Зниження інтенсивності забарвлення цитоплазми нейронів тіоніном вказує на патогістологічні процеси та ослаблення функціонального стану клітини.

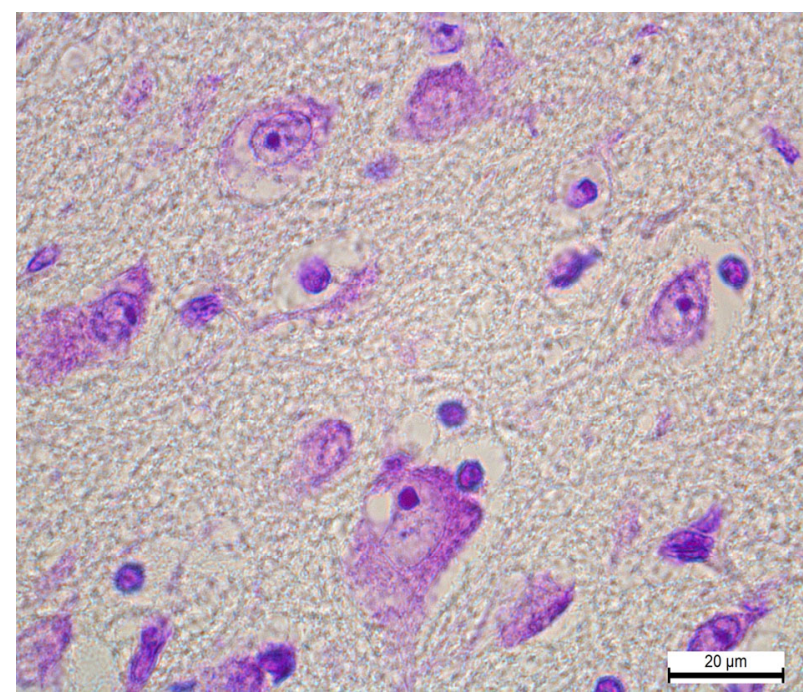

Рис. 10. Кора головного мозку кота. Перицелюлярний набряк. Хроматоліз цитоплазми нейронів. Ніссль.

Ок. 10 , об. 100

клітинах прогресувало значне набухання їхнього тіла та відростків (рис. 11). Цитоплазма деяких зірчастих клітин заповнювалась різними за величиною прозорими міхурцями, які частіше розміщувались периферично. Отже, в зірчастих нейронах кори головного мозку розвивалась у різній мірі виражена гідропічна дистрофія (рис. 12).

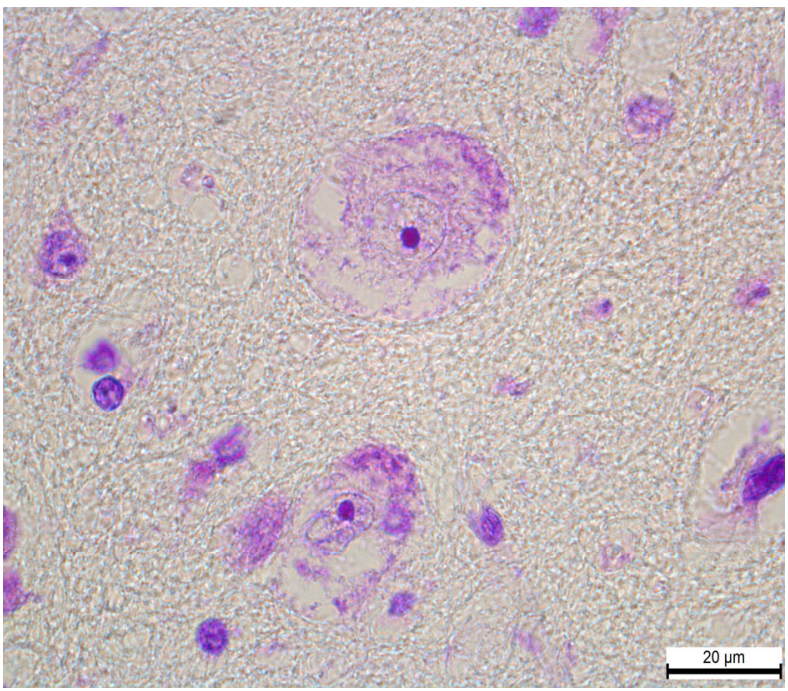

Рис. 12. Кора головного мозку кота. Гідропічна дистрофія зірчастих клітин. Ніссль. Ок. 10, об. 100 
У деяких зірчастих нервових клітинах кори головного мозку спостерігали втрату ядрами оболонки, в результаті чого в центрі клітин залишається погано сформована базофільна маса без ядерець. В інших клітинах ядра лізовані, вони перетворювались у неоднорідно забарвлені безструктурні форми. Каріоцитоліз супроводжувався тяжким захворюванням клітин утворенням клітин-тіней (рис. 13). Відзначали хрома-

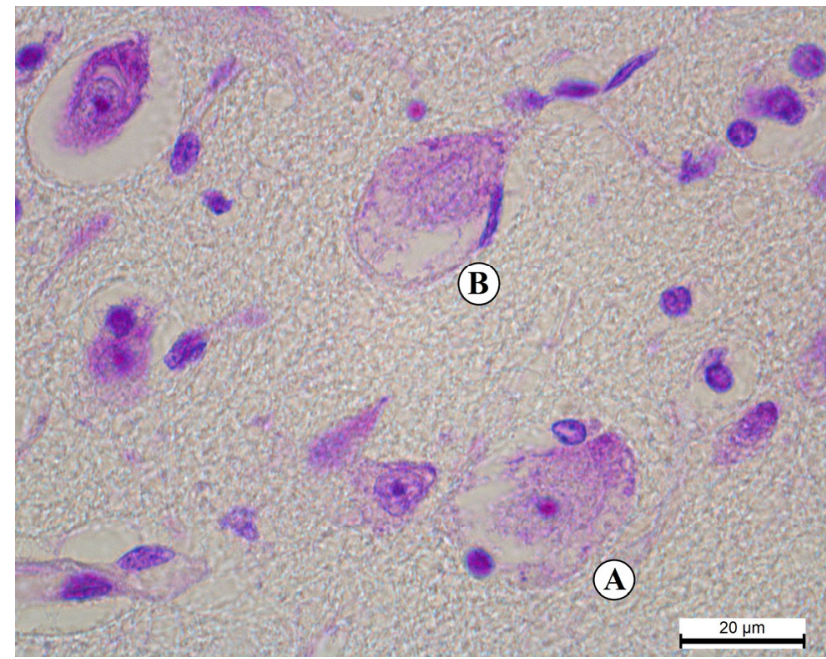

Рис. 13. Кора головного мозку кота. А - гідропічна дистрофія зірчастих клітин, В - каріоцитоліз (клітинатінь). Ніссль. Ок. 10, об. 100

\section{Обговорення}

Варто зазначити, що в досліджуваних котів нами попередньо було встановлено зміни у легеневій тканині 3 розвитком артериїтів, продуктивнонекротичних васкулітів і периваскулярних неспецифічних гранулем, що, звісно, вело до звуження просвітів судин, порушення трансорганного кровообігу і зокрема гемоциркуляції в головному мозку (Kotsiumbas et al., 2016). Відомо, що головний мозок $є$ дуже чутливим до нестачі кисню та глюкози, які потрапляють в тканину саме через систему кровообігу.

Виявлені нами гістоструктурні зміни в головному мозку вказували на недостатність транспортної системи кори і перивентрикулярної ділянки, що зумовило анемію, гіпоксію, набряк і водянку бокових шлуночків. Порушення структурної організації ендотеліальних клітин, базальних мембран капілярів та венул кори головного мозку варто розглядати як важливий показник функціональних змін тонусу, проникності мікроциркуляторного русла, що спричиняло розвиток периваскулярних і перицелюлярних набряків, посилення дистрофічних змін як у макрогліоцитах, так і нейронах.

\section{Висновки}

1 За гістологічного дослідження лобної ділянки кори головного мозку котів встановлено зміни незапального характеру, які характеризувались розладами толіз і периневральну базофільну інкрустацію в пірамідних клітинах. У трикутної форми клітинах дрібнозернистий хроматин дифузно розміщувався по всій гіалоплазмі, а це зумовлювало світліше забарвлення цитоплазми і відростків. Ядра округлої форми, з ледь голубуватою каріоплазмою, в яких проглядались ядерця. Біля основи пірамідних клітин розміщувались слабо забарвлені олігодендроцити (рис. 14).

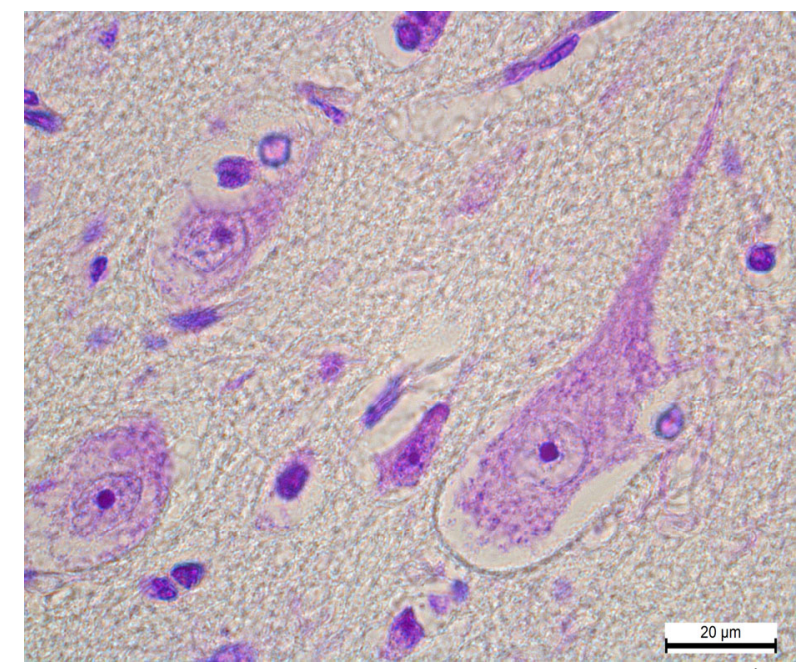

Рис. 14. Кора головного мозку кота. Зниження вмісту хроматофільної речовини у пірамідній клітині та гідропічна дистрофія зірчастого нейрона. Ніссль.

Ок. 10, об. 100

гемомікроциркуляції, регресивними змінами гліальних елементів, гострим набуханням нейронів з мікровакуолями в ядрах, різким зниженням вмісту хроматофільної субстанції в пірамідних і зірчастих клітинах, розвитком гідропічної дистрофії в зірчастих клітинах II і III шарів та каріоцитолізом 3 утворенням клітин-тіней.

2. Розлади кровообігу зумовили порушення роботи транспортних систем трофіки, що викликало гіпоксію, нагромадження кислих продуктів обміну і лягло в основу патогенезу розвитку дисциркуляторних дистрофій нейрогліальних елементів та нейронів кори головного мозку котів за FIP.

\section{References}

Barnes, H.L., Chrisman, C.L., Mariani, C.L., Sims, M. \& Alleman, A.R. (2004). Clinical signs, underlying cause, and outcome in cats with seizures: 17 cases (1997-2002). Journal of the American Veterinary Medical Association, 225(11), 1723-1726. doi: 10.2460/javma.2004.225.1723.

Baydar, E., Eröksüx, Y., \& Timurkan, M.O. (2014). Feline infectious peritonitis with distinct ocular involvement in a cat in Turkey. Kafkas Üniversitesi Veteriner Fakültesi Dergisi, 20(6), 961-965. doi: $10.9775 / \mathrm{kvfd} .2014 .11195$.

Diaz, J.V. \& Poma, R. (2009). Diagnosis and clinical signs of feline infectious peritonitis in the central nervous sys- 
tem. The Canadian Veterinary Journal, 50 (10), 10911093. https://www.ncbi.nlm.nih.gov/pubmed/20046611.

Ermohin, P.N. (1969). Gistopatologija nervnoj sistemy. Moskva: Medicina (in Russian).

Filimonov, I.N. (1959). Anatomija i gistologija nervnoj sistemy. Moskva: "Medgiz" (in Russian).

Goral's'kyj, L.P., Homych, V.T., \& Konons'kyj, O.I. (2005). Osnovy gistologichnoi' tehniky i morfofunkcional'ni metody doslidzhen' $\mathrm{u}$ normi ta pry patologii' [Bases of histological technology and morphofunctional methods of research in norm and in pathology]. Polissja, Zhytomyr (in Ukrainian).

Ives, E.J., Vanhaesebrouck, A.E. \& Cian, F. (2013). Immunocytochemical demonstration of feline infectious peritonitis virus within cerebrospinal fluid macrophages. Journal of Feline Medicine and Surgery, 15(12), 1149-1153. doi: 10.1177/1098612X13491960.

Kim, Y., Liu, H., Kankanamalage, A.C.G., Weerasekara, S., Hua, D.H., Groutas, W.C., Chang, K.-O., \& Pedersen, N.C. (2016). Reversal of the Progression of Fatal Coronavirus Infection in Cats by a Broad-Spectrum Coronavirus Protease Inhibitor. PLoS Pathogens, 12(3), e1005531. doi: 10.1371/journal.ppat.1005531.

Kotsiumbas, G., Pritsak, V., \& Khalaniia, M. (2016). Patomorfolohichni zminy lehenevoi tkanyny za infektsiinoho perytonitu kotiv. Nauk. visnyk LNUVMB im. S.Z. Hzhytskoho, 3(70), 161-166 (in Ukrainian).

Majzelis, M.Ja. (1973). Gemato-jencefalicheskij bar'er i ego reguljacija. Moskva: Medicina (in Russian).

Merkulov, G.A. (1969). Kurs patologogystolohycheskoj tekhnyky [The course of pathohistological technique]. L.: Medycyna (in Russian).

Mesquita, L.P., Hora, A.S., Siqueira de A., Salvagni, F.A., Brandão, P.E. \& Maiorka, P.C. (2016). Glial response in the central nervous system of cats with feline infectious peritonitis. Journal of Feline Medicine and Surgery, 18 (12), 1023-1030. doi: 10.1177/1098612X15615906.

Pedersen, N.C. (2014a). An update on feline infectious peritonitis: virology and immunopathogenesis. The Veterinary Journal, 201(2), 123-132. doi: $10.1016 / j . t v j 1.2014 .04 .017$.
Pedersen, N.C. (2014b). An update on feline infectious peritonitis: Diagnostics and therapeutics. The Veterinary Journal, 201(2), 133-141. doi: 10.1016/j.tvj1.2014.04.016.

Pedersen, N.C., Liu, H., Dodd, K.A., \& Pesavento, P.A. (2009). Significance of Coronavirus Mutants in Feces and Diseased Tissues of Cats Suffering from Feline Infectious Peritonitis. Viruses, 1(2), 166-184. doi: $10.3390 / \mathrm{v} 1020166$.

Pedersen, N.C., Liu, H., Durden, M., \& Lyons, L.A. (2016). Natural resistance to experimental feline infectious peritonitis virus infection is decreased rather than increased by positive genetic selection. Veterinary Immunology and Immunopathology, 171, 17-20. doi: 10.1016/j.vetimm.2016.01.002.

Pedersen, N.C., Liu, H., Gandolfi, B., \& Lyons, L.A. (2014). The influence of age and genetics on natural resistance to experimentally induced feline infectious peritonitis. Veterinary Immunology and Immunopathology, 162(1-2), 33-40. doi: 10.1016/j.vetimm.2014.09.001

Pyrs, Je. (1962). Gistohimyja. Moskva: Yzdatel'stvo inostrannoj lyteratury (in Russian).

Rissi, D.R. (2018). A retrospective study of the neuropathology and diagnosis of naturally occurring feline infectious peritonitis. Journal of Veterinary Diagnostic Investigation, 30(3), 392-399. doi: $10.1177 / 1040638718755833$.

Skoromec, A.A., Skoromec, A.P., Skoromec, T.A. (2004). Topicheskaja diagnostika zabolevanij nervnoj sistemy. Sankt-Piterburg: Politehnika (in Russian).

Skrebkova, O.Ju. (2004). Ul'trastrukturna morfologija aerogematichnogo bar'yera v umovah alkogol'noï intoksikacii v eksperymenti ta u ljudyny. Avtoreferat kand.med.nauk. Simferopol' (in Ukrainian).

Ziółkowska, N., Paździor-Czapula, K., Lewczuk, B., Mikulska-Skupień, E., Przybylska-Gornowicz, B., Kwiecińska, K., \& Ziółkowski, H. (2017). Feline Infectious Peritonitis: Immunohistochemical Features of Ocular Inflammation and the Distribution of Viral Antigens in Structures of the Eye. Veterinary Pathology, 54(6), 933-944. doi: 10.1177/0300985817728557. 